\title{
Foreign Direct Investments in Albania, Structure and Dynamics
}

\author{
Dr. Klaudeta Merollari \\ Department of Finance-Accounting, Faculty of Economy, \\ Fan S. Noli University, Korçë, Albania \\ klaudetamerollari2010@hotmail.com
}

Msc. Sorina Koti

Department of Finance-Accounting, Faculty of Economy,

Fan S. Noli University, Korçë, Albania

sorinakoti@gmail.com

\begin{abstract}
After the fall of communism regime, Albania has become a host country to foreign direct investments (FDI) from many countries around the world. Albania represents four of the five types of FDI: those which gain access to specific factors of production; those which gain access to disposable production factors; those which gain access to Albanian consumer markets and those which organize joint ventures. Our country widely supports the FDI as there are no high taxation and commerce barriers to gain access to the new markets. Foreign direct investments are a very important segment of the economic activity of a country. In theory and also in practice, there are recognized the effects of FDI. They have brought significant positive effects on the economy. One of the advantages of FDI is that they help in the economic development of the country where is invested.FDI are usually applied in developing countries. During the 90 s, they were one of the major external financial sources for most countries that had an economic growth perspective. FDI have been a significant support for some countries which faced economic difficulties. The main aim of this paper is to analyze the theoretical part and the relations of FDI in general.Another aim of this paper is to provide a general picture of FDI in Albania over the years, the main sectors where they are centralised, districts / cities where they are allocated, and so on.At the beginning it is given a theoretical framework, definitions and relations of FDI to various economic aspects. Then it is described the evolution in time and the development of FDI in different levels, for example in the countries of origin, currency in which it is mostly invested, main sectors, etc. There is also a comparison of FDI in Albania in relation to other countries in the region and beyond. We have mentioned here also the factors that affect FDI.
\end{abstract}

Keywords: foreign direct investments, economic development, remittances

Foreign direct investments are considered to be one of the most important pillars of the economy of a country, especially of the economy of developing countries. Foreign direct investments provide the necessary capital for the economic growth and technological development of a country. In developing countries, emerging economies and countries in transition, foreign direct investments have become a very important source of economic development, modernization, employment and revenue growth. They are considered as an engine that gives power to the economy by helping in technology development, creation of new jobs and increase of productivity.

Foreign direct investments in Albania, as well as in other countries of Central and Eastern Europe are one of the new ways of Western capital penetration, especially during the transition toward a market economy.

Before the 90s Albania was the poorest country in Europe, because of the economic and social system. At that time the economy was based on state property, it was centralized and state controlled.

The main aim of this paper is to reflect the situation of FDI in Albania over the years, that is their geographical and sectional distribution as well as maximum and minimum values from 90s until now. 


\section{Foreign Direct Investments in Albania according to the State of Origin}

During 2013 the state of origin of most FDI in Albania is Greece with 1.1 milliard euro or $31 \%$ of the total. Other important states with regard to FDI are Austria (11\%), the Netherlands (10\%) and Turkey (8\%). An interesting fact to be mentioned is the value of FDI of Italy and the Czech Republic for 2013 which appear negative, this means that there are investors who had invested previously in Albania and who in 2013 have transferred their investments to the country of origin or other countries.

Table: 1 Foreign direct investment in Albania according to the origin (million euro)

\begin{tabular}{|l|l|l|l|l|l|l|l|l|l|l|}
\hline $\begin{array}{l}\text { Count } \\
\text { ry }\end{array}$ & Austria & $\begin{array}{l}\text { German } \\
\text { y }\end{array}$ & Greece & Italy & USA & $\begin{array}{l}\text { Leban } \\
\text { on }\end{array}$ & $\begin{array}{l}\text { Turke } \\
\mathbf{y}\end{array}$ & $\begin{array}{l}\text { Netherl } \\
\text { and }\end{array}$ & $\begin{array}{l}\text { Czech } \\
\text { Republ } \\
\text { ic }\end{array}$ & Other \\
\hline $\mathbf{2 0 1 3}$ & 377.94 & 106.86 & $\begin{array}{l}1070.4 \\
3\end{array}$ & $\begin{array}{l}(132.8 \\
2\end{array}$ & 51.5 & 29.96 & $\begin{array}{l}279.3 \\
4\end{array}$ & 350.57 & $\begin{array}{l}(307.53 \\
)\end{array}$ & $\begin{array}{l}720.9 \\
7\end{array}$ \\
\hline
\end{tabular}

\section{Source: Bank of Albania}

Figure: 1 Foreign direct investment in Albania according to the origin

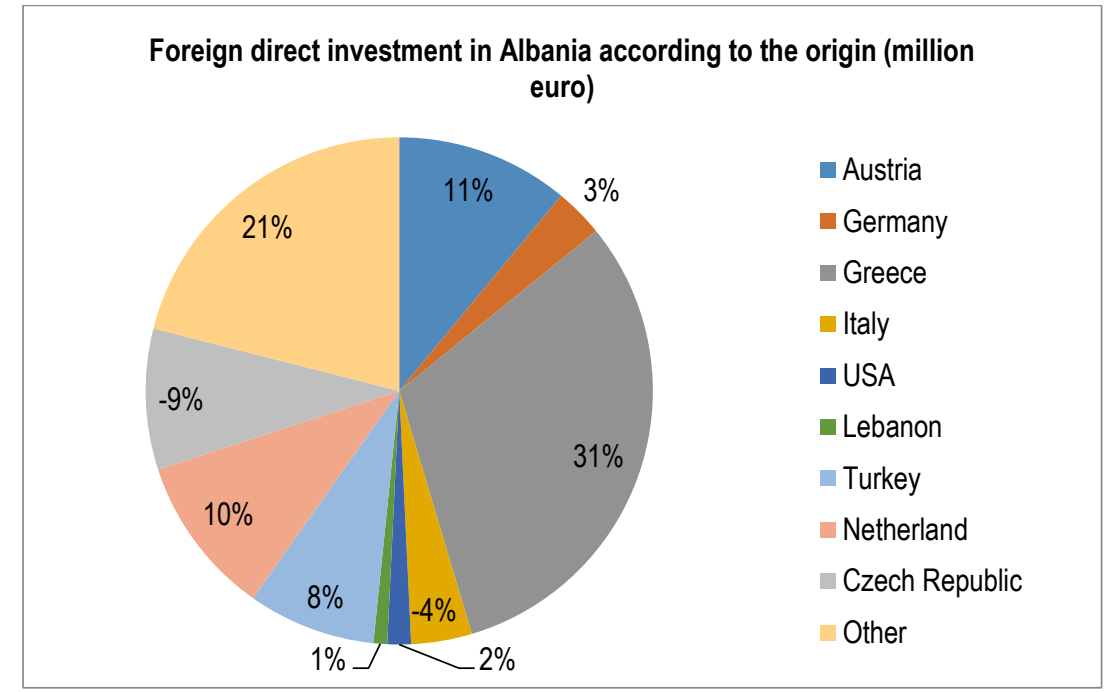

Source: Bank of Albania

Foreign Direct Investments are still predominated by Greek investitures. In the time frame of 2007-2013 FDI in Albania have mostly originated from Greece, and have increased continuously.

\section{Foreign Direct Investments in the Republic of Albania according to their origin 2007-2013}

Table:2 Foreign direct investments in Albania according to the origin (2007-2013) 


\begin{tabular}{|c|c|c|c|c|c|c|c|}
\hline \multicolumn{8}{|c|}{ Values in million euro } \\
\hline Country & 2007 & 2008 & 2009 & 2010 & 2011 & 2012 & 2013 \\
\hline Austria & 146.72 & 186.42 & 220.54 & 353.69 & 443.60 & 386.61 & 377.94 \\
\hline Germany & 52.39 & 66.18 & 74.45 & 83.84 & 83.60 & 92.06 & 106.86 \\
\hline Greece & 520.56 & 565.61 & 559.63 & 601.05 & 507.45 & 766.54 & $1,070.43$ \\
\hline Italy & 220.10 & 321.46 & 347.86 & 386.79 & 427.36 & 124.77 & (132.82) \\
\hline USA & 72.44 & 74.91 & 24.10 & $(97.72)$ & $(47.23)$ & 35.89 & 51.50 \\
\hline Lebanon & 29.72 & 40.45 & 36.07 & 28.05 & 29.36 & 39.27 & 29.96 \\
\hline Turkey & 154.05 & 189.70 & 235.12 & 186.66 & 187.78 & 234.77 & 279.34 \\
\hline Netherland & 273.88 & 187.90 & 207.33 & 222.67 & 253.05 & 297.38 & 350.01 \\
\hline $\begin{array}{l}\text { Czech } \\
\text { Republic }\end{array}$ & - & 0.01 & 55.38 & $(11.56)$ & $(15.22)$ & $(220.21)$ & (307.53) \\
\hline Others & 359.72 & 428.52 & 556.34 & 670.94 & $1,514.93$ & $1,284.24$ & 720.97 \\
\hline TOTAL & $1,829.58$ & $2,061.15$ & $2,261.44$ & $2,435.97$ & $3,399.90$ & $3,261.53$ & $2,854.19$ \\
\hline
\end{tabular}

Source: Bank of Albania

In total for 2013, the situation of FDI was 2.85 milliard EUR. This value seems to be lower than in previous years where the value of FDI was respectively 3.26 milliard euro in 2012 and 3.4 milliard euro in 2011.

Table: 3 Foreign Direct Investments in Albania 2007-2013

Values in million euro

\begin{tabular}{|l|l|l|l|l|l|l|l|}
\hline Year & 2007 & 2008 & 2009 & 2010 & 2011 & 2012 & 2013 \\
\hline
\end{tabular}




\begin{tabular}{|l|l|l|l|l|l|l|l|}
$\begin{array}{l}\text { TOTAL of } \\
\text { FDI }\end{array}$ & $1,829.58$ & $2,061.15$ & $2,261.44$ & $2,435.97$ & $3,399.90$ & $3,261.53$ & $2,854.19$ \\
\hline
\end{tabular}

Figure: 2 Foreign Direct Investments in Albania 2007-2013

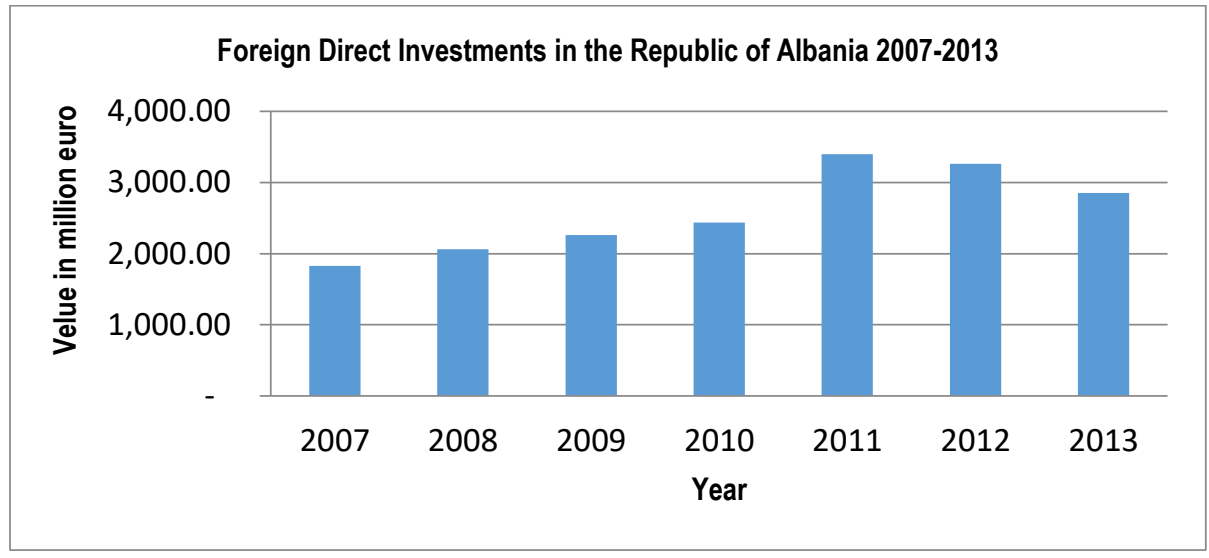

Source: Bank of Albania

2. Foreign Direct Investments according to economic activity

Table: 4 Foreign Direct Investments according to economic activity

Foreign Direct Investments according to economic activity 2013

\section{Value in million euro}

Sector

Agriculture, hunting and forestry

Fishing

Extraction industry

Manufacturing industry

Production and distribution of electricity, gas, steam and hot water

Construction

Wholesale and retail market, repair of automobiles, motorcycles, personal and house 136.76 equipments

Hotels and restaurants

63.59

Transport, storage, communication 


\begin{tabular}{ll}
\hline Financial and monetary intermediation & 780.12 \\
Real estate, rent, informatics, scientific research, other professional activities & 307.23 \\
Education & 9.51 \\
Health and other social activities & 33.34 \\
Other activities linked to collective, social and personal services & 17.33 \\
Activities of international organizations & 59.74 \\
Other industries & 61.10 \\
Total & $2,854.21$ \\
\hline
\end{tabular}

Source: Bank of Albania

Figure: 3

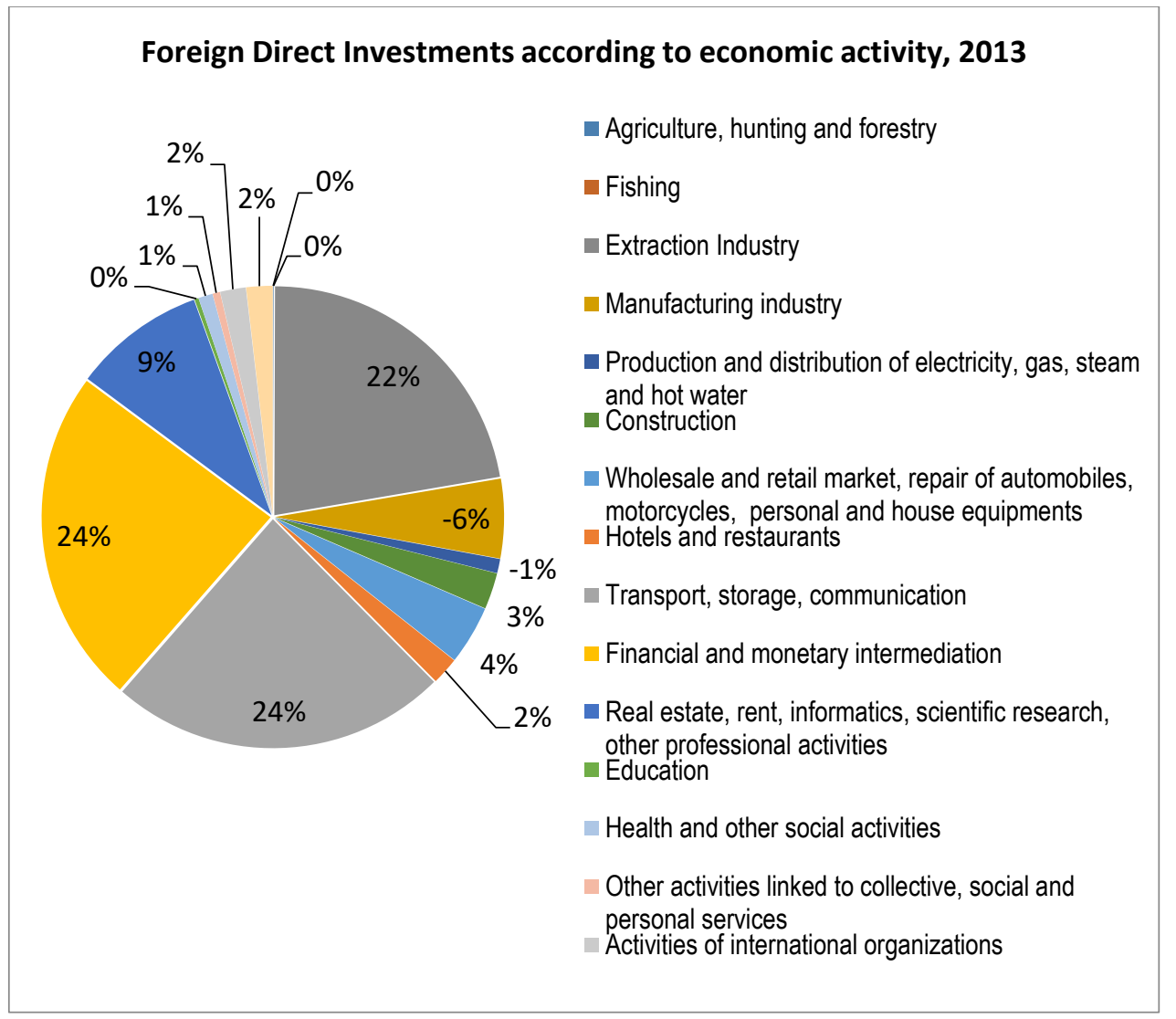

Most of FDI in the Republic of Albania for 2013 were in the sector of transport, storage and communication, followed by financial and monetary intermediation, extraction industry etc. 
Over the years the situation of FDI in Albania has changed. During 2007-2011 the main FDI were in financial and monetary intermediation, while in 2012 in the sector of extraction industry and in 2013 in the sector of transport, storage and communication.

It is worth to be mentioned the situation in the sector of "Manufacturing Industry" and the "Production and distribution of electricity, gas, steam and hot water" where foreign direct investment in 2013, unlike previous years indicate negative values, which means the withdrawal of foreign investors from these sectors.

Table: 5 Foreign Direct Investments according to Economic Activity during 2007-2013

\begin{tabular}{|c|c|c|c|c|c|c|c|}
\hline Sector & 2007 & 2008 & 2009 & 2010 & 2011 & 2012 & 2013 \\
\hline $\begin{array}{l}\text { Agriculture, hunting and } \\
\text { forestry }\end{array}$ & 5.85 & 18.90 & 6.38 & 7.33 & 3.94 & 1.56 & 1.57 \\
\hline Fishing & - & 2.08 & 3.19 & 1.68 & 3.77 & 0.10 & $(0.08)$ \\
\hline Extraction industry & 10.47 & 29.31 & 146.63 & 311.42 & 611.79 & 809.98 & 732.10 \\
\hline Manufacturing industry & 217.81 & 363.17 & 352.01 & 378.04 & 431.21 & 387.83 & (184.23) \\
\hline $\begin{array}{l}\text { Production and distribution of } \\
\text { electricity, gas, steam and hot } \\
\text { water }\end{array}$ & 10.37 & 17.64 & 95.18 & 117.75 & 246.54 & 8.66 & $(33.03)$ \\
\hline Construction & 132.08 & 196.38 & 188.78 & $(0.91)$ & 10.78 & 77.84 & 84.33 \\
\hline $\begin{array}{l}\text { Wholesale and retail market, } \\
\text { repair of automobiles, } \\
\text { motorcycles, personal and } \\
\text { house equipments }\end{array}$ & 99.47 & 270.95 & 252.74 & 240.06 & 216.69 & 153.07 & 136.76 \\
\hline Hotels and restaurants & 94.11 & 93.91 & 78.50 & 76.18 & 69.85 & 63.69 & 63.59 \\
\hline $\begin{array}{l}\text { Transport, storage and } \\
\text { communication }\end{array}$ & 590.44 & 383.20 & 356.70 & 399.54 & 388.75 & 437.25 & 784.83 \\
\hline $\begin{array}{l}\text { Financial and monetary } \\
\text { intermediation }\end{array}$ & 587.57 & 547.56 & 613.85 & 699.61 & 715.28 & 753.45 & 780.12 \\
\hline $\begin{array}{l}\text { Real estate, rent, informatics, } \\
\text { scientific research, other } \\
\text { professional activities }\end{array}$ & 57.38 & 25.29 & 42.31 & 62.58 & 82.93 & 84.68 & 307.23 \\
\hline Education & 1.63 & 2.80 & 2.72 & 4.41 & 5.93 & 8.28 & 9.51 \\
\hline $\begin{array}{l}\text { Health and other social } \\
\text { activities }\end{array}$ & 0.08 & 25.69 & 47.51 & 63.94 & 46.85 & 37.47 & 33.34 \\
\hline $\begin{array}{l}\text { Other activities linked to } \\
\text { collective, social and personal } \\
\text { services }\end{array}$ & 12.69 & 8.33 & 8.91 & 11.97 & 8.82 & 18.32 & 17.33 \\
\hline
\end{tabular}




\begin{tabular}{|l|l|l|l|l|l|l|l|}
\hline $\begin{array}{l}\text { Activities of international } \\
\text { organizations }\end{array}$ & - & - & 10.29 & 24.44 & 36.18 & 45.67 & 59.74 \\
\hline Other industries & 9.63 & 75.95 & 55.75 & 37.92 & 520.58 & 373.68 & 61.10 \\
\hline Total FDI & $\begin{array}{l}1,829.5 \\
8\end{array}$ & $\begin{array}{l}2,061.1 \\
6\end{array}$ & $\begin{array}{l}2,261.4 \\
5\end{array}$ & $\begin{array}{l}2,435.9 \\
6\end{array}$ & $\begin{array}{l}3,399.8 \\
9\end{array}$ & $\begin{array}{l}3,261.5 \\
3\end{array}$ & $2,854.21$ \\
\hline
\end{tabular}

Foreign Direct Investments are an important indicator of the confidence that foreign investors have in a country. They decrease in terms of economic and political crises and increase in cases of improvement of economic and political environment. In the time frame of 2007 - 2013 Foreign Direct Investments in Albania have increased and then have declined in the last two years.

\section{Business climate and foreign investments in Albania}

Why investing in Albania?

- $\quad$ Strategic Position

- Free access to the markets - Free trade agreements (CEFTA , EFTA with other countries) create opportunities for access to a wider market;

- $\quad$ Member of the IMF since 1991, the WTO since 2000, and NATO since 2009;

- In 2006, Albania signed the Stabilization and Association Agreement (SAA) with the European Union.

- In 2014, Albania received the candidate status of the European Union

- Albania has a liberalized economic framework and conditions for doing business as well as attracting FDI are improving constantly.

Table: 6 Macroeconomic Indicators

\begin{tabular}{|l|l|l|l|l|l|l|l|l|}
\hline & $\mathbf{2 0 0 6}$ & $\mathbf{2 0 0 7}$ & $\mathbf{2 0 0 8}$ & $\mathbf{2 0 0 9}$ & $\mathbf{2 0 1 0}$ & $\mathbf{2 0 1 1}$ & $\mathbf{2 0 1 2}$ & $\mathbf{2 0 1 3}$ \\
\hline $\begin{array}{l}\text { Real GDP } \\
\text { Growth (\%) }\end{array}$ & 5.4 & 5.9 & 7.5 & 3.32 & 3.8 & 3.1 & 1.6 & 0.7 \\
\hline $\begin{array}{l}\text { GDP } \\
\text { (current } \\
\text { account price, } \\
\text { euro billion) }\end{array}$ & 6.3 & 6.9 & 8.9 & 8.7 & 8.9 & 9.2 & 9.7 & 9.73 \\
\hline $\begin{array}{l}\text { Unemployment } \\
\text { \% of } \\
\text { population }\end{array}$ & 13.8 & 13.2 & 12.7 & 13.8 & 13.5 & 13.3 & 13.4 & 12.9 \\
\hline $\begin{array}{l}\text { Inflation rate } \\
\text { Public Debt }\end{array}$ & 2.5 & 3.1 & 3.4 & 2.3 & 3.6 & 3.5 & 2.0 & 1.9 \\
\hline \begin{tabular}{l} 
(as \% of GDP) \\
\hline
\end{tabular} & 53.5 & 54.7 & 59.4 & 58.5 & 59.5 & 61.9 & 62 \\
\hline
\end{tabular}

The government is engaged in identifying and finding new sources that will ensure sustainable development of Albanian economy. Ongoing reforms aim to increase the efficiency of administration, tax collection and to fight corruption. 
Some of the incentives for the promotion of foreign investments are:

- Honest taxation constitutes the backbone of fiscal policy; who earns more, will contribute more.

- In Albanian tax system there is not any distinction between foreign and domestic investors;

- Albania has signed an agreement with many countries in order to eliminate double taxation.

- Dynamic, educated and competitive workforce;

- $\quad$ Over 1 million well educated young professionals;

- More than $57 \%$ of the population is under 35 years old;

- 116,292 students in higher education;

- English and Italian languages are widely spoken. French and German languages are included in the education system. Other languages of the region are widely spoken;

- $\quad$ The minimum salary in Albania is 22,000 ALL (157 EUR);

- The average salary (in the public and private sector) is 36,075 ALL (266 EUR).

Attracting foreign investments, especially in sectors where Albania has a real potential, will remain a priority for the future development of the economy.

Energy, tourism, agribusiness, mining industry, and ICT are sectors with great priority for investments in Albania.

\section{ALBANIAN ECONOMIC COMPETITIVNESS}

Albania has made significant progress in recent years. An indication for this is "The Global Competitiveness Report 20112012" of the World Economic Forum, which ranks Albania in 78th place among 142 economies, while during 2010-2011 Albania was ranked in 88th place and in 2009-2010 in 96th place.

According to the World Bank report "Doing Business 2012", in the "Ease of doing business", Albania was ranked in the 82th place out of 183 economies. In "Getting Credit" and "Protection of investors", Albania was ranked respectively in the 24th and in 16th place, being among the best reformers.

Current Progress is evident by another significant indicator that is "Index of Economic Freedom" which was published by "The Heritage Foundation" and "Wall Street Journal". According to the Index of 2012, the economic freedom in Albania is 65,1 which ranks it in the $57^{\text {th }}$ place among 164 countries / economies in the world. The level of economic freedom is increased by 1.1 points compared to the end of the year report, where Albania was ranked in the $70^{\text {th }}$ place with 64 points.

Table: 7 REGIONAL CORE INDICATORS

\begin{tabular}{|l|l|l|l|}
\hline \multirow{2}{*}{ Countries } & Change of GDP & Annual inflation & Unemployment rate \\
\cline { 2 - 4 } & $\mathbf{2 0 1 3 / 2 0 1 2}$ & $\mathbf{2 0 1 3}$ & $\mathbf{2 0 1 3}$ \\
\hline Italy & $-1,9$ & 0,7 & 12,7 \\
\hline Greece & $-3,0$ & $-1,8$ & 27,82 \\
\hline Macedonia & 3,3 & 1,4 & 28,71 \\
\hline Serbia & 3,7 & 2,2 & 20,12 \\
\hline Croatia & $-0,6$ & 0,3 & 17,41 \\
\hline Turkey & 4,4 & 7,4 & 9,72 \\
\hline Kosovo & 2,53 & 0,5 & 30,93 \\
\hline
\end{tabular}




\begin{tabular}{|l|l|l|l|}
\hline Albania & $-2,3$ & 1,9 & 12,81 \\
\hline
\end{tabular}

\section{Source: www.aida.gov.al}

\section{THE INDEX OF ECONOMIC FREEDOM}

Economic Freedom Index 2014 ranks Albania in the $54^{\text {th }}$ place with an improvement of four places in the world classification. Its overall index is increased by 1.7 points, with notable progress in freedom of investment and trade. Albania is ranked in the $25^{\text {th }}$ place among 43 countries in Europe, and its overall score is above the world average.

According to the Index of Economic Freedom 2015 Albania in ranked in the $29^{\text {th }}$ place among 43 countries in Europe, and its overall score is above the world average.

Figure: 4

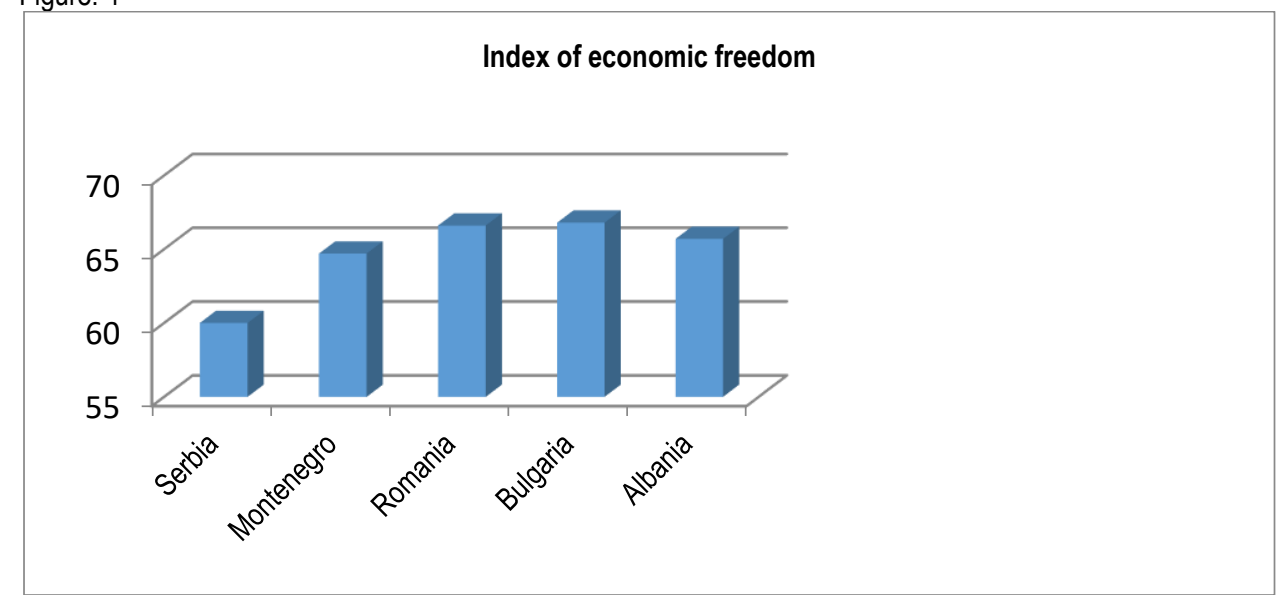

Source: Index of Economic Freedom 2015

www.heritage.org/index/country/albania

\section{Labour Force}

Albania offers not only a highly skilled labour force, but also with the lowest cost in the Region. The relations between employers and employees are regulated by individual employment contracts, according to the Labour Code of the Republic of Albania and Law no. 8549, dated 11.11.1999 "The status of civil servants".

The minimum salary in Albania is 22,000 ALL (starting from 01.07.2011), about 157 EUR. Basic minimum salary is monthly paid for 8 hours per day. 
Figure: 5 Basic minimum salary in EUR (January 2015) - Compared to the region

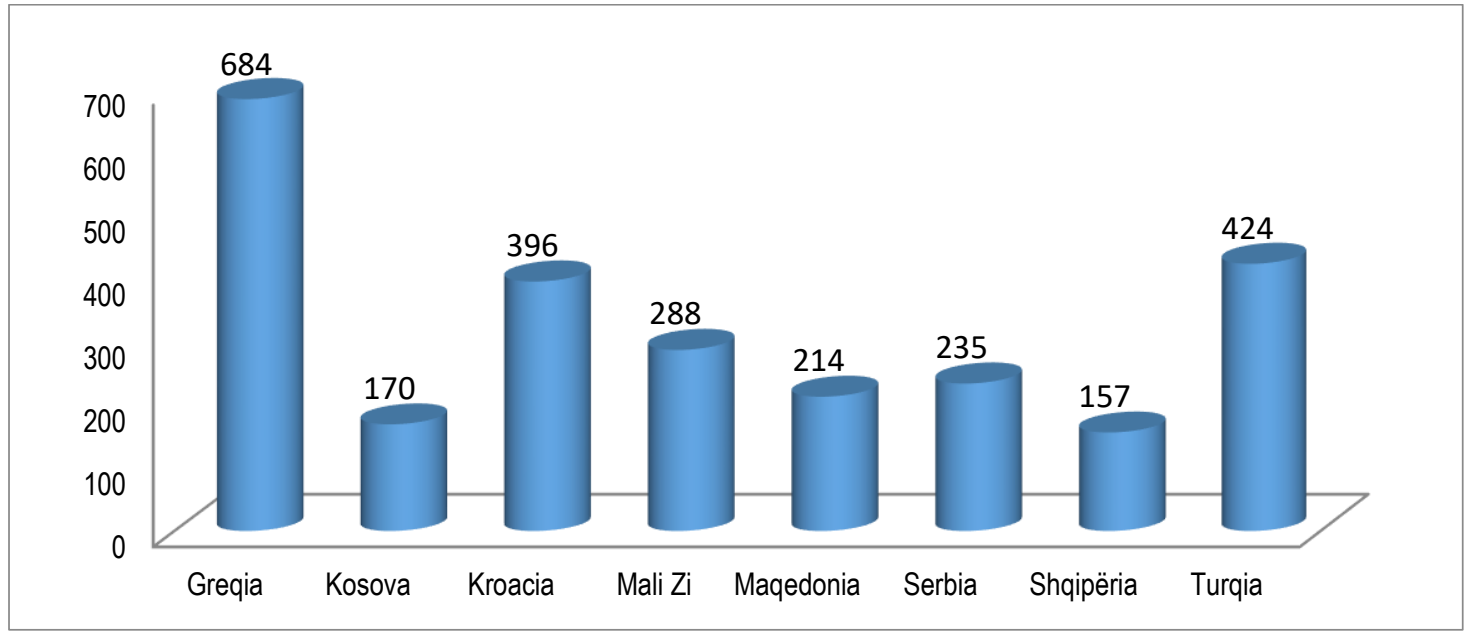

Source: Eurostat; International Federation of Employment

According to INSTAT data, the average salary (public and private sector) is 36,075 ALL (about 266 EUR).

Figure:6 Average gross salary in EUR - Compared to the region

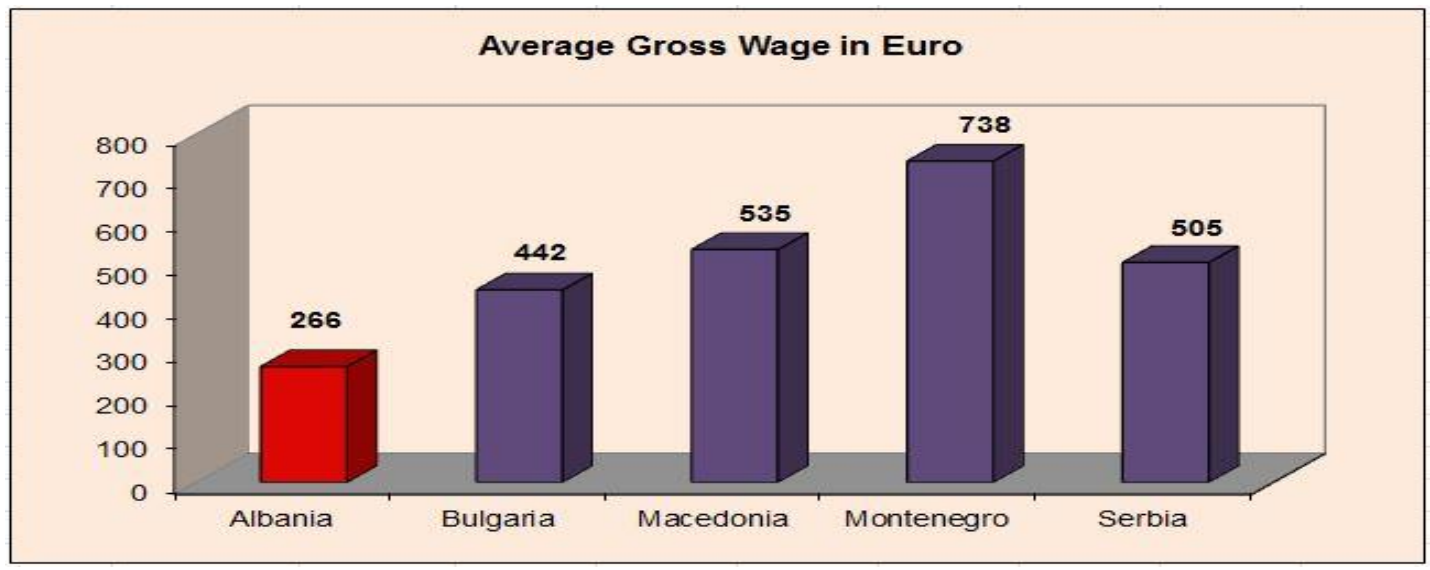

Source: Federation of European Employers, SIEPA, INSTAT

\section{Conclusions}

- $\quad$ Foreign direct investments are very important for the development and economic growth of a country. For countries like Albania with a centralized economy run by the state until the $90 \mathrm{~s}$, FDI are one of the best ways to penetrate foreign capital and to fundamentally change the economic structure of the country.

- Foreign Direct Investments bring different impacts on the economy of the host country, so in addition to strengths, they have also their disadvantages. It should be stressed that in Albania the inflow of foreign direct investments has generally had positive effects.

- Foreign Direct Investments in Albania have different origin, but they are not very variable over the years. The majority of investments are coming from the neighbouring countries part of the European Union that is Greece 
and Italy. Meanwhile, another significant part of FDI, especially in recent years comes from Turkey, which investments trend grow year after year. While very small percentage (compared to the total) occupies the United States of America and Germany.

- $\quad$ Foreign direct investments are oriented toward commerce, and are followed by industry, mainly processing industry and then construction and transport. FDI in commerce are generally import-export, and the rest are in industry and industrial capital investments. The sector with the smallest influence, in terms of distribution of FDI is agriculture, mainly because of the problems that this sector has, that is the ownership issues and transformation and rehabilitation of desolate land.

- Regarding the territorial distribution of FDI, they are concentrated in two main cities, Tirana and Durres, because Tirana is the capital of Albania and Durres has the largest port in the country.

- The level of FDI in the last two decades has had its variations, but in general there is an increasing tendency for these kinds of activities, due to the business climate that Albania provides and the policies that favour foreign investors.

- Foreign investments in Albania have brought their generally positive effects that are: added value, employment, increase of productivity and economic development.

\section{References}

[1] Estrin S. Uvalic M. (2013) "Foreign direct investment into transition economies: Are the Balkans different" LSE Europe in Question Discussion paper series

[2] Ganic M. (2013) "The effects of Foreign Direct Investment flows in developing process of countries of Western Balkan"

[3] Lall S. (2002) FDI and development: research issues in the emerging context. Edited by Bora B. (2002) Foreign Direct Investment Research Issues. Routledge London, New York.

[4] Lee B. (2002) FDI from Developing Countries - A Vector for Trade and Development, OECD, MA 01923 USA.

[5] Nakuçi V., Zizo K, (2005) "Foreign direct investment the promoter of growth in the Albanian economy"; SouthEast Europe Review $1 / 2006$

[6] Zakarov V.(2004) "The Role of FDI in the EU Accession Process: The Case of the Western Balkans

[7] World Bank (2006) "Investment Horizons: Western Balkans"

[8] www.bankofalbania.org

[9] www.aida.gov.al

[10] ec.europa.eu/eurostat

[11] www.financa.gov.al 